\title{
Engaging Student Teachers in An Online Teaching Pedagogies Module during COVID-19
}

\author{
Peter Tiernan ${ }^{1}$, Jane O’Kelly² \& Justin Rami ${ }^{2}$ \\ ${ }^{1}$ School of STEM, Innovation and Global Studies, Institute of Education, Dublin City University, Ireland \\ ${ }^{2}$ School of Policy and Practice, Institute of Education, Dublin City University, Ireland \\ Correspondence: Peter Tiernan, School of STEM, Innovation and Global Studies, Institute of Education, Dublin City \\ University, Ireland.
}

Received: June 1, 2021

Accepted: July 19, 2021

Online Published: July 20, 2021

doi:10.5430/ijhe.v10n7p62

URL: https://doi.org/10.5430/ijhe.v10n7p62

\begin{abstract}
COVID 19 represented a major challenge for many educators, with teachers needing to pivot rapidly to using online learning tools in order to stay connected with their students. This was particularly relevant for teachers in the process of completing their Initial Teacher Education (ITE), whose programmes of study did not include online teaching components. The objective of this study was to develop and evaluate a module for teaching in online and blended learning environments for 244 post-primary teachers in ITE. This study begins by examining the impact of COVID-19 and the resulting pivot to online learning, this includes an overview of the challenges associated with online teaching. Next, the authors explain the module in detail, outlining the tools, strategies and activities provided for student teachers. This included peer-evaluated online micro-teaching components - which formed a major part of the learning. Data collection involved a questionnaire which gathered student teachers' perceptions of the module and its approaches, the impact it had on their ability to teach during the COVID-19 pandemic, and the knowledge and skills useful for future practice. Findings suggested that the implementation of the developed module was successful in preparing student teachers to teach online, providing them with the tools and confidence necessary for success. Improvements suggested the development of differentiated pathways for student teachers who are more experienced with online teaching.
\end{abstract}

Keywords: online teaching, initial teacher education, student teachers

\section{Introduction}

The COVID-19 pandemic resulted in seismic shifts to the delivery of education around the world throughout 2020 and 2021. Institutions from across the spectrum were faced with extremely challenging situations, with many forced to close their doors entirely. The post-primary sector in Ireland closed on numerous occasions throughout this period and universities were closed (and remain closed) to face-to-face teaching for the duration of the pandemic. These closures presented major challenges for the continuation of teaching and learning in Ireland (QQI, 2020). The closure of both the post-primary and university sectors was particularly impactful on student teachers who were completing their Initial Teacher Education (ITE). Not only were these student teachers completing their university qualification remotely, they were also required to complete their professional school placement by teaching their own (post-primary) students online. This paper represents the evaluation of a response developed for the Professional Masters in Education (PME) programme at Dublin City University. The response aimed at supporting student teachers in the successful completion of their professional placement by providing them with the knowledge and skills to successfully engage their students in online learning. Thus, the objectives of the study were:

(1) To develop an effective online teaching pedagogies module which prepares student teachers for online placement in schools

(2) To evaluate the benefits of the module to student teachers for teaching online during placement, and their future teaching practice

(3) To improve online teaching modules that can respond to student teacher learning needs on placement and in their professional practice as teachers.

\section{Background}

The 2020 Covid-19 pandemic worldwide impacted everyone, no more so than educators in schools, early childhood, 
further and higher education environments. The response from governments and educational settings internationally has been varied and has re-ignited the debate about face-to-face and online learning and teaching. However, there is no doubt that pre-pandemic, online teaching and learning was increasing exponentially worldwide albeit with some caveats. Hurlbut (2018) points out that online course offerings are not a new phenomenon; however, virtual learning is emerging in the realm of traditional pre-service teacher education programmes. The current shift from synchronous face to face teaching to predominantly online teaching was immediate. Hodges et al. (2020) contend that this switch should be called "Emergency Remote Teaching (ERT)" to distinguish it from high quality online teaching. The distinctions between online teaching and ERT include the lack of time for the application of systematic design and/or universal design approaches for accessibility. Chau (2010) contends that we may need to slow down the online learning bandwagon and take time to re-examine our reasons for promoting online learning and make more salient the issues that are being left out of the discussion when it comes to online learning. Hodges et al. (2020) suggest that ERT is a way of thinking about delivery modes, methods, and media, specifically as they map to rapidly changing needs and limitations in resources, such as faculty support and training.

ITE programmes, like many higher education offerings, experienced a pivot to online teaching and learning that was unprecedented and unpredicted in March 2020. The experience of changing from a face-to-face traditional teaching model to an online virtual learning environment taught many educators that their digital skills needed an upgrade. The impact of the Covid-19 pandemic on education settings proved to be a catalyst and an accelerant for the implementation of online teaching, although Downing \& Dymant (2013) suggest that the prospect of a shift toward online teaching can be exciting, daunting, or even terrifying. The context of this shift and its daunting nature must be considered in relation to the current provision on ITE programmes in Ireland. No training currently exists which prepares student teachers to teach online and so there was a need for content which introduces online teaching approaches, pedagogies and digital tools and supported the pivot to online teaching.

Singh and Thurman (2019, cite Lee, 2017; Moore et al., 2011; Ryan et al.,2016) who state that: "when used interchangeably, online education/e-Learning has been generally defined as the bridging of the space between the teacher and the student through the use of web-based technologies" (p.293). Saba and Shearer (2018) would argue "that [educators] persistence in replicating the face-to-face experience in our online courses keeps us rooted in the industrial/modern era of higher education, and shifts need to occur at institutional and societal levels for us to move to a post-industrial/post-modern era of personalization and adaptability" (cited in Shearer et al, 2020, p.49). A systematic review of teacher attitudes to online teaching in ITE found a divided, unsettled, and challenging space with pockets of acceptance, but characterised by epistemological and pedagogical questions, doubts, and uneasiness (ibid, 2020). Some of the teacher education literature has focused on the main challenges of preparing teachers to teach within an online environment (Sutherland-Smith \& Saltmarsh, 2010). A significant challenge for those pivoting to remote and online teaching is to ensure that the 'relationship' element to the student-teacher experience is understood and nurtured. The social aspect of the experience is vital to student engagement. Berger and Lyon (2005) urge caution regarding how these online technologies impact the social interaction of students with their educator and their institution. Daves \& Roberts (2010) posit that it is important that teacher education programmes understand the benefits of online courses, and that success lies within the connectedness students feel through the effective use of online technologies. With respect to psychological considerations for students in an online learning environment Shearer et al. (2020) found that "students need to be challenged to step out of their comfort zone in a psychologically safe online environment, where they feel that they can fail without any detrimental consequences". As Mottus et al. observe "while the teacher's role as a content delivery expert may be reduced in ubiquitous learning environments, the need for their pedagogical skills in effective facilitation has, if anything, increased in importance" (2018, p. 550). Noddings (2004) argues that it is not the job of teachers simply to secure demonstrable learning on a pre-specified set of objectives and that the teacher role cannot be reduced merely to a set of skills. Assessment and feedback are intrinsically linked and are therefore two sides of the same coin rather than separate entities.

The importance of teacher placement in authentic educational settings as part of ITE has increased in recent years. The Teaching Council of Ireland (2015) states that 'It is a critical part of initial teacher education (ITE) as it enables the student teacher to experience teaching and learning in a variety of contexts, and to participate in school life in a way that is structured and supported'. The work of teachers at all stages is complex, and this complexity can increase as student teachers encounter the content of their courses and begin to experience the work of teachers in their school field placements (Beltman, Glass et al., 2015). The teaching practice also offers a meaningful space to exercise reflection in collaboration with peers and tutors that can contribute to the process of learning to teach (Fuentes-Abeledo, 2020). The impact of Covid-19 on higher education and compulsory education and the central role of placement in ITE was at best problematic and limited (due to space constraints and health and safety) and at worse, impossible due to multiple 
long-term closures of school buildings and limited access to online teaching resources and training to use them. Kidd \& Murray (2020, p.533) see "the closure of schools and the removal of the practicum as a matter not just of 'pedagogic agility' and technological innovation but also as a matter of spatial re-orientation: the 'move' to online and private-become professional spaces through 'online-at-home-working"'.

It is clear that the COVID-19 pandemic presented an unprecedented challenge to student teachers on ITE programmes. Teaching online is a complex endeavour which has received little attention on ITE programmes to-date. This, coupled with the importance of their teaching placement, highlighted the need for an intervention to support student teachers. In response to this, an online teaching pedagogies module was designed and written to equip student teachers with the necessary knowledge and competencies to teach online throughout a period of school closures. It was envisaged that this intervention would support student teachers in dealing with the 'significant change from traditional learning environments, in which students, in peer groups, and teachers interact face to face for content delivery' (Mottus et al., 2018). The module was delivered over one semester to 244 students studying to be teachers in post-primary education. This module was taught fully online using Zoom, Loom and a learning management system on a Moodle platform. This study examined the findings from a summative evaluation of the student experience in terms of their learning, response to teaching strategies and assessment, and the relevance and value of the module to teaching online while on placement.

\section{Methodology}

\subsection{Participants}

This study was conducted in the Institute of Education at Dublin City University. Participants were 244 student teachers studying for a Professional Masters in Education (PME). They took part in a module titled 'Teaching in Online and Blended Learning Environment', which was delivered during semester one to both first and second year students on the programme. All participants on the module were invited to complete the questionnaire. Thus, convenience sampling was used as a selection mechanism, as it provided researchers with ease of access to the participants. The module was designed in response to the COVID-19 pandemic and aimed to equip student teachers to continue their online teaching, including professional placement, during the school closures in Ireland in late 2020 early 2021.

\subsection{Research Instruments}

Data were collected from students at the end of the academic year using an anonymous online questionnaire. The questionnaire contained 20 questions spread across four main themes: perceptions of module content; perceptions of assessment approaches; application of learning; and looking to the future. Each theme contained a range of questions, many of which included statements to which students responded with the extent to which they agreed, along with space to provide supporting statements. For example, in the theme 'perceptions of assessment approaches', students were provided with the statement 'Peer feedback helped me to identify my strengths and weaknesses'. To which they could respond $1=$ strongly disagree, $2=$ somewhat disagree, $3=$ neither disagree nor agree, $4=$ somewhat agree, $5=$ strongly agree, and provide a statement to support their answer. Out of the 244 students, 82 completed questionnaires were received, giving a response rate of $34 \%$.

\subsection{Description of Intervention}

The purpose of this intervention was to equip student teachers with the necessary knowledge and competencies to teach online throughout a period of school closures. As such, the module was created using five pillars of content. First, students were provided with a historical perspective on technology in education, to give students context and perspective. Second, key educational theories related to online and blended learning were introduced. These included 'community of inquiry' (Garrison et al., 2000), 'connectivism' (Siemens, 2004) and the 'online learning model' (Anderson, 2011). The objective here was to raise awareness of the variety of perspectives and approaches to be considered in online learning, rather than a deep critique of any single theory or approach. Third, lectures were provided on synchronous delivery (webinars), including practical training on tools such as Zoom and Google classroom. Fourth, lectures were provided on the opportunities and challenges associated with asynchronous delivery, and included practical training on tools such as Loom, EdPuzzle and Vyond. Finally, lectures were provided on the integration of discussion through forums using tools such as Google classroom. A key component of this intervention was the innovative assessment approach. Students were divided up into small $(n=5)$ assignment groups. Each member of the group was required to deliver a short teaching episode (micro-teaching) to their group, using each of the modalities covered during the module (synchronous, asynchronous, forum facilitation), after which they received peer-feedback from their group. The final element of the module assessment was the completion of a reflective 
document which required students to look back on their teaching episodes and, taking into account the peer-feedback received, comment on how they could develop their knowledge and competence.

\subsection{Data Analysis}

Analysis of both the quantitative and qualitative data was carried out using well established practices and approaches. Quantitative data (extent of agreement) was analysed using descriptive statistics, while qualitative data was coded using thematic analysis (Creswell, 2017). Thematic analysis involved the systematic coding of student data in which specific statements were analysed and categorised into themes that represented areas of interest in relation to the research objectives. Key findings are now presented under the thematic areas outlined above. Themes are addressed using quantitative data (rated responses) and supported with students' comments.

\section{Findings}

Findings are now presented using quantitative data and selected excerpts from students' qualitative responses.

\subsection{Perceptions of Module Content and Delivery}

In this section, students were asked a series of questions to gather their perceptions of the module, indicating how the content and delivery methods supported their learning and prepared to teach online (see Table 1). Most students (95\%) felt that the module served an important purpose and that the aims were clear. Students commented that it was 'P5 easy to understand why we were doing it and what was involved' and that 'P6 - in the time of great stress this module was delivered in a clear way'. Comments indicated that the structure of the module allowed students to visualise their progression and tackle the content in manageable chunks. They commented that 'P54 - The module was broken into areas that were well defined and was well laid out so as to cover one area of learning at a time' and 'P74 - all objectives were clearly explained and carried through the module to the end'. A small number of students (5\%) were less sure saying 'P61 - sometimes I felt unsure on what to do' and 'P79 - it was difficult to understand the structure at the beginning but it became clearer as the weeks went on'. The vast majority of respondents agreed that the module content $(88 \%)$, delivery techniques (93\%) and resources (92\%) that were provided to them supported their learning and prepared them for teaching online. Students felt that the module content 'P8 - prepared us well for real-world application' and 'P38 - for different challenges of teaching online'. They commented that having content 'P80 broken down into manageable sections' allowed them to get a 'P83 - sense of the different learning platforms'. However, some students (11\%) were less positive, feeling that 'P7 - more in-depth material' could have been provided and that 'P77 - it should have been a year long module to be offered a chance to learn about the use of a number of online tools and activities specific to our individual subjects'. Students said that the delivery techniques helped them to 'P67 - scaffold my learning' so that they felt 'P54 - better equipped to use the different types of learning' and that they understood the 'P56 - elements of online teaching and learning I had previously been unfamiliar with'. Some students (7\%) were less positive, stating that 'P28 - delivery could have been more hands-on' and 'P68 - at times the content was over simplified and aimed at students with less technological experience than myself'. Students found the resources very helpful, saying that the resources were 'P7 - really high quality' and 'P9 - very helpful to refer back to'. They found the zoom lectures and recordings particularly beneficial as they 'P34 - promoted interaction and kept students engaged'. Students also commented on the accessibility of resources, with one student saying 'P50 - every resource was very accessible, easy to navigate and directly related to the content of the course. I liked that extra materials were available to complement the lectures'. However, some students $(7 \%)$ were less positive, feeling that 'P38 - more support of the various teaching platforms such as Teams, Google classroom' would have helped, and that they 'P51 - would [have] liked some more links to readings and maybe some external research for my own development and understanding'.

Table 1. Perceptions of module content and delivery

\begin{tabular}{lllllll}
\hline Question & 1 & 2 & 3 & 4 & 5 & Total \\
\hline $\begin{array}{l}\text { The objectives and purpose of the module were clear } \\
\begin{array}{l}\text { The module content supported my learning and } \\
\text { prepared me to teach online }\end{array}\end{array}$ & $1 \%$ & $0 \%$ & $4 \%$ & $20 \%$ & $75 \%$ & $\mathrm{~N}=82$ \\
$\begin{array}{l}\text { The module delivery supported my learning and } \\
\text { prepared me to teach online }\end{array}$ & $0 \%$ & $1 \%$ & $6 \%$ & $28 \%$ & $65 \%$ & $\mathrm{~N}=82$ \\
$\begin{array}{l}\text { The module resources supported my learning and } \\
\text { prepared me to teach online }\end{array}$ & $0 \%$ & $2 \%$ & $5 \%$ & $23 \%$ & $69 \%$ & $\mathrm{~N}=81$ \\
\hline
\end{tabular}


Student teachers were asked to rate their agreement with the above statements using the rating scale: $1=$ strongly disagree, 2 = somewhat disagree, $3=$ neither disagree nor agree, $4=$ somewhat agree, $5=$ strongly agree. Percentage of total responses, along with total number of responses are provided in the table.

\subsection{Perceptions of Assessment Approaches}

In this section, students were asked a series of questions to gather their perceptions of the assessment approaches used, how they supported their learning and prepared them to teach online (see table 2). Students appeared to see the benefit in the peer assessment approaches adopted, feeling that it not only helped them to develop their skills, but it also helped them to connect with other learners during a period of isolation. $85 \%$ of students agreed that the peer assessment helped them to develop their skills, saying that 'P9 - It was really helpful to learn from others in the course, and it was a supportive environment' and 'P17 - It was beneficial to receive feedback from teachers who are in the same position as me', with another adding that 'P22 -the peer assessment felt well thought out and not just "Rate your mate". They encouraged critical feedback outside of grading and then allowed me to reflect on what I could do better in my own teaching'. $76 \%$ of students agreed that peer assessments helped them to identify their strengths and weaknesses in relation to online teaching, they said that 'P9 - I learned a lot both from watching my peers, and from the feedback they have me, as their different perspectives showed me new ways of approaching my work', 'P6 - I got to see what my other peers were doing and I could implement their techniques into my lessons' and 'P32 - I was able to use the feedback to consider how I could improve for the next assignment, and how I could improve as a teacher'. While students were predominantly positive about the peer assessment process, some found the experience less beneficial, and this seemed to centre on the quality of the peer feedback received. Students commented that 'P13 - it was difficult to see if people were being honest or just saying they thought it was good. Some critique that I did receive was welcome and this was helpful', another student said there was 'P67 - sometimes a lack of constructive criticism with peer assessment'. Similarly, one student said 'P23 -I felt that my peers were not completely honest, they would not say every weakness just one and possibly 2 strengths', with another saying 'P50 - at times from my group members it seemed somewhat generic feedback as opposed to me specifically'.

Most students (84\%) also found the reflective essay to be of benefit as a tool for reflecting on and improving their practice. They commented that 'P5 - it made me think about where I could improve' and 'P19 - I felt helped me gauge the extent of learning and areas i need to focus on' and 'P27 - the reflective assessment allowed me to look back on my approach and take into consideration the feedback I got, so it helped me identify how I could improve'. Of those that were less agreeable (16\%), comments included 'P77 - I don't see any purpose in doing an essay on what we learned. I would have preferred to spend some more time on learning more about tools for making our presentations more captivating'.

Table 2. Perceptions of assessment approaches

\begin{tabular}{|c|c|c|c|c|c|c|}
\hline Question & 1 & 2 & 3 & 4 & 5 & Total \\
\hline $\begin{array}{l}\text { The peer assessments supported the development of my } \\
\text { online teaching skills }\end{array}$ & $0 \%$ & $6 \%$ & $8 \%$ & $30 \%$ & $55 \%$ & $\mathrm{~N}=82$ \\
\hline $\begin{array}{l}\text { Peer feedback helped me to identify my strengths and } \\
\text { weaknesses }\end{array}$ & $2 \%$ & $8 \%$ & $12 \%$ & $18 \%$ & $58 \%$ & $\mathrm{~N}=82$ \\
\hline $\begin{array}{l}\text { The reflective assessment supported the development of } \\
\text { my online teaching skills }\end{array}$ & $4 \%$ & $1 \%$ & $11 \%$ & $28 \%$ & $56 \%$ & $\mathrm{~N}=82$ \\
\hline
\end{tabular}

Student teachers were asked to rate their agreement with the above statements using the rating scale: $1=$ strongly disagree, 2 = somewhat disagree, $3=$ neither disagree nor agree, $4=$ somewhat agree, $5=$ strongly agree. Percentage of total responses, along with total number of responses are provided in the table.

\subsection{Impact of the Module on Teachers Experience of Teaching Online during COVID-19}

In this section, student teachers were asked a series of questions to ascertain the impact of the module on their experience of teaching online during the COVID-19 pandemic (see table 3). Students overwhelmingly agreed that participation in the module had a positive impact on their ability to teach online (94\%), their confidence levels $(88 \%)$, and their ability to engage their students in online environments (78\%). Students said that 'P4 - without this module I would not have been able to teach online', that they 'P9 - felt prepared to take in on' and that the module gave them the skills to 'P6 - create more asynchronous lessons and content for my students, allowing them the opportunity to learn at different times'. The module also had a very positive impact on teachers' confidence levels, they commented that before the module they were 'P58 - only guessing how to do things' but the module provided 'P58 - best practice with 
blended learning and online teaching and learning' and that it 'P32 - gave me more assurance that I was providing good content and offered alternative ways of interacting with students'. Students felt 'P6 - more confident to teach online as I have become more comfortable with apps and online platforms to deliver my lessons' with some being able to 'P25 - able to offer suggestions and assist other qualified teachers'. Students also felt better equipped to provide environments and activities to engage their learners. They commented that it 'P30 - gave me ideas' and helped them to 'P22 - reframe my online classroom space to one that better engaged my students'. They were 'P31 - more aware of methods that would be particularly engaging for students during remote learning' and learned 'P63 - how to improve and encourage communication in online classes'. There were some students who felt less of an impact on their ability to teach online (6\%), and their confidence (10\%). The sentiment from these students was that they already possessed the required skills and knowledge, saying they 'P21 - already had good knowledge of the content' and that they were 'P78 - trained by my placement school'. Of those that felt less of an impact on their ability to engage their students online (21\%), comments indicated that engagement 'P19 - depends on the individual student and home life' and with 'P60 - engagement being a discipline issue' and students needing to be 'P67 - their own motivator for engagement'.

Table 3. Impact of the module on teachers experience of teaching online during COVID-19

\begin{tabular}{lllllll}
\hline Question & 1 & 2 & 3 & 4 & 5 & Total \\
\hline $\begin{array}{l}\text { Participation in the module improved my ability to teach } \\
\text { online on placement during the COVID-19 pandemic }\end{array}$ & $2 \%$ & $0 \%$ & $4 \%$ & $11 \%$ & $83 \%$ & $\mathrm{~N}=82$ \\
$\begin{array}{l}\text { Participation in the module improved my confidence in } \\
\text { using technology to teach online on placement during } \\
\text { the COVID-19 pandemic }\end{array}$ & $2 \%$ & $1 \%$ & $7 \%$ & $8 \%$ & $80 \%$ & $\mathrm{~N}=82$ \\
$\begin{array}{l}\text { Participation in the module improved my ability to } \\
\text { engage my students in online learning on placement } \\
\text { during the COVID-19 pandemic }\end{array}$ & $1 \%$ & $8 \%$ & $12 \%$ & $22 \%$ & $56 \%$ & $\mathrm{~N}=82$ \\
\end{tabular}

Student teachers were asked to rate their agreement with the above statements using the rating scale: $1=$ strongly disagree, $2=$ somewhat disagree, $3=$ neither disagree nor agree, $4=$ somewhat agree, $5=$ strongly agree. Percentage of total responses, along with total number of responses are provided in the table.

As part of this section, students were asked if there was a specific part of the module (tool, approach, method) that helped them to teach online during the pandemic. While many students commented about the benefit of being introduced to a wide range of approaches and tools, some specific themes did emerge. The most prominent of these (20 comments) was the introduction to asynchronous teaching strategies and tools such as Loom to create recorded content. For example, students mentioned the 'P25 - asynchronous lecture on how to make lessons interactive and engaging', commenting that the 'P13 - introduction to Loom and recording presentations was perhaps the most helpful' and 'P51 - definitely loom and the learning of asynchronous learning'. A significant proportion of comments (16 comments) spoke of synchronous teaching strategies and using tools such as zoom to facilitate webinars and live teaching sessions. Students commented that 'P5 - the tools for live lessons really helped'. Specifically, students mentioned a number of tools on zoom such as 'P9- knowledge of screen sharing' and 'P12 - the use of chat function' which resulted in an overall 'P16 - building of confidence to conduct zoom classes'. Other specific areas which arose through comments (2 comments) were the use of forums and blogs as teaching resources.

This data suggests that providing student teachers with a dedicated intervention designed to prepare them to teach in online environments is a worthwhile and important strategy for consideration. Student teachers recognise online teaching as an important aspect of their future practice and as a separate set of approaches and skills that need to be developed and nurtured in order to increase their confidence and abilities in this area. Student teachers need to be provided with the opportunity to engage with the range of methodologies and technical possibilities if they are to be able to operate online in a confident manner. Student teachers value the division of the approaches into bespoke categories (synchronous and asynchronous) as it allows them to consider their effectiveness in different scenarios with their students.

\subsection{Future Application of the Knowledge and Skills Gained}

In this section, students were asked a series of questions to ascertain if the knowledge and skills developed through the module would be applied in the future teaching - post-pandemic (see table 4). The vast majority of students (91\%) agreed that the skills they learned would be applied in their future teaching. They commented that 'P22 - I feel online teaching is in the future, and what I learned here will help me apply it to classes', 'P58 - I have used some of those 
skills already into the classroom and they will benefit my teaching in the future for sure' and 'P8 - skills I have learned go far beyond online teaching and I will certainly employ them in the classroom'. Some students mentioned specific strategies such as 'P5 - flipped classrooms' and 'P11 - I think message boards will be a big part of future teaching with teachers using it a lot now to compliment physical teaching'. Of those that were less agreeable (9\%), comments included 'P27 - if online teaching were to return' and 'P66 - I hope we do not have to return to online teaching'. $90 \%$ of students agreed that the tools and technologies they learned on the module would be used in their lessons in the future. They commented that they will 'P6 - continue to use them as they are beneficial to my students', that they 'P25 - supplement and support my classroom teaching' and 'P51 - tools I learned will be used in my teaching going forward and will contribute to my development as a future Educator'. Some stated that already 'P32 - used strategies and resources from this module' for tasks such as 'P38 - assigning homework and activities'. Of those that were less agreeable (10\%), comments included 'P79 - I was previously using some of these tools anyway' and 'P27 - not in person teaching'.

Table 4. Future application of the knowledge and skills gained

\begin{tabular}{llllllc}
\hline Question & 1 & 2 & 3 & 4 & 5 & Total \\
\hline $\begin{array}{l}\text { Teaching/facilitation skills I learned on the module will } \\
\text { be applied in my future teaching }\end{array}$ & $1 \%$ & $2 \%$ & $6 \%$ & $20 \%$ & $71 \%$ & $\mathrm{~N}=82$ \\
$\begin{array}{l}\text { Tools and technologies I learned on the module will be } \\
\text { used in my lessons in my future teaching }\end{array}$ & $2 \%$ & $1 \%$ & $7 \%$ & $22 \%$ & $68 \%$ & $\mathrm{~N}=82$ \\
\hline
\end{tabular}

Student teachers were asked to rate their agreement with the above statements using the rating scale: $1=$ strongly disagree, 2 = somewhat disagree, $3=$ neither disagree nor agree, $4=$ somewhat agree, $5=$ strongly agree. Percentage of total responses, along with total number of responses are provided in the table.

\section{Discussion}

\subsection{Perceptions of Module Content and Delivery}

Shearer et al. (2019, p. 322) suggest "learners are highly autonomous, and have control of their own learning process. They are motivated, self-controlled, and self-monitored. They learn through engaging in deep discussions and interactions with their peers and instructors and solve real-life challenging problems with critical thinking and metacognitive processes. Instructors are facilitators, negotiators, and guides". The accelerated move to online teaching and learning for lectures and for teachers of teachers in ITE did not allow for time for comprehensive needs analysis or research when designing ERT training inputs. The supplementing of existing Information and Communication Technology (CT) and Technology Enhanced Learning (TEL) modules focused on the change in teaching practice as required by schools and policy guidelines. Cohen (2020) suggests that a more inclusive or aligned pedagogy is required for online learning, "One in which the learning design and the facilitation of learning is considered independent of its classroom-based predecessor, and its mainstay, the lecture which is so pedagogically inherent in classroom-based teaching and learning practice". The learning design of the Online Pedagogies module, its structured content and range of resources and modes of access proved valuable to students and demonstrated an 'aligned pedagogy' for pre-service teachers. Although outside of the scope of the first roll-out of this module, the challenge for future iterations is to provide more diverse and differentiated routes for self-directed learning for students who are technologically literate and interested in the underpinning theory and research of online learning as an approach. Students who take a deep approach have the intention of understanding, engaging with, operating in, and valuing the subject (Lalor et al, 2014, p.49).

\subsection{Perceptions of Assessment Approaches}

Dewey's (1938) philosophy of students gaining from and drawing learning out of 'meaningful experiences' combined with Sadler's (1998) concept of 'opening and closing of feedback loops' all support the concept of feedback as part of assessment being a dialogical process. Therefore, feedback structure is set up as a tripartite framework and includes the lectures, the learners, and their peers. The majority of students (85\%) indicated that peer assessment is a valuable tool in supporting the development of online teaching competencies with student teachers. Receiving feedback from peers was seen as highly useful in facilitating reflection and improvement of practice. However, it also provides students with the opportunity to witness and learn from the tools, strategies and approaches being adopted by their peers. Some students felt that the quality of peer feedback was lacking, perhaps an unwillingness or an inability from peers to provide constructive feedback to avoid offending or upsetting a peer or friend. Students may benefit from a refresh of learning on the peer feedback process to improve professional practice. In the context of assessment and peer feedback 
it is important that student teachers are introduced to scenarios that reproduce real life contexts that allow them to reduce 'practice shock' (Van Huizen et al., 2005). Such learning scenarios should require them not only to perform skilfully but also to express their creativity, individuality and most importantly their principled judgement (Lalor, et al, 2014). An honest examination of the psychological processes involved in peer feedback may illuminate student understanding and provide professional scaffolding on assessment and its application as assessment-for-learning as well as assessment-on-learning. Ashenafi $(2017$, p.246) found that "students, especially in the initial stages, are often critical of their peers' ability in assessing their work". He recommends that further research is needed on whether "this criticism has foundation or arises from bias".

The majority of students $(84 \%)$ found the reflective essay a useful tool for improvement of their learning and their practice. Reflective practice in itself can be challenging for some. Maloney et al., (2013) found in their study of reflection by students in health professional education that, "Key influences for engaging students in honest reflection include whether the task is summative, the design of any assessment criteria, the level of training students receive in the process of critical reflection with particular attention to emotions raised, and the student's perception of the activities relevance to the overall goal of becoming a reflective practitioner". The minority of students who appear frustrated with the reflective essay and process may have been confused by the module's emphasis on practical learning and skills acquisition in a crisis and the perceived lack of urgency for reflective practice. The module design acknowledges that within the feedback process in teacher education, it is important that the development of existing knowledge acts as an aid to cultivate critical thinking (Pennel et al, 2007) thus enhancing the development of a life-long reflective attitude in professional practice.

\subsection{Impact of the Module on Teachers Experience of Teaching Online during COVID-19}

The responses of student teachers demonstrate that the provision of practical training and demonstrations of relevant and appropriate online teaching Apps and software can increase confidence and alleviate stress. Yildiz \& İşman (2016, p.2858) suggest that the "quality of content is one of the factors that determine the quality of education in distance learning". The students appreciated the module content that focused on modelling the use of online tools for effective and engaging online teaching. Archibald, Graham \& Larson (2020) cite Lopez-Belmonte et al's (2020) study of vocational teachers in Spain where it was found that $52 \%$ of teachers in the study, who avoided blended teaching altogether, stated that their main reason for doing so was a lack of training in using pedagogical technology (López-Belmonte et al., 2020). The perceived need for a 'toolbox' of interactive, engaging, enjoyable tools for teaching and learning was provided through exposure to asynchronous recording techniques, software and Apps that provided alternative online teaching strategies that could provide a simulacrum for traditional trusted strategies such as think, pair, share and group work. Student teachers appreciated the confidence that they felt from having access to such a toolbox and an ability to engage students using technology.

Shearer et al. (2020, p.47) found that the student's view of their ideal online learning experience "needs to be a collaborative and constructive process through which learners engage in critical discourse, create meaning of the processes and content, and form a sense of "me" as the part of a community of inquiry". While this holds true for student teachers learning how to teach, the challenge for student teachers is also to model this collaborative and constructive process while engaging their students in online learning. The placement experience for student teachers can be challenging. Fuentes-Abledo et al., $(2011$, p.62) points out that it is useful to "think of the future teacher as an active adult learner, committed to their learning, influenced by their personal history and prior experience as well as by the nature of the context in which it happens and who they interact with to construct unique, distinct, idiosyncratic meanings and interpretations'. Carrillo \& Flores (2020) contend that a clear pedagogy of online education should underpin any online teaching. As such,

"this should integrate technology as an inherent part of the online teaching and learning process and take into account the pedagogical possibilities associated with online tools, i.e., the suitability and affordances of the various technologies or online resources (e.g., blogs promote discussions and facilitate reflective practice; videos help develop practical knowledge about the profession and connect educational theory with practice; online forums enable the sharing of narratives that enhance the skill of noticing; breakout or chat rooms foster belongingness and high levels of support and cooperation among group members) to make sure that the chosen tools or resources help learners achieve the desired results" (p. 478).

The online pedagogies module provided student teachers with the opportunity to use online tools to engage students including specific apps and software as well as online platforms and processes that encourage interaction and engagement. The experiential application of this knowledge and skill development provided the student teachers with the confidence to teach online. The engagement of students is dependent on a wide set of variables including the 
pedagogical approach of the teacher but also access issues, digital literacy, and the student ability to troubleshoot technical glitches.

\subsection{Future Application of the Knowledge and Skills Gained}

The responses from student teachers reflect the certainty that the skills and knowledge gained from the module will be of benefit to them post pandemic in a future learning environment that is still uncertain. Teachers are called on to be activators of meaningful learning, not just facilitators, being creative in choosing from a wide palette of strategies to be mixed and adjusted to context and learner (Caena \& Redecker, 2019, p.357). It appears that views of student teachers on the future learning environment can vary which may relate in part to their subjective experience of placement schools where access to information and communication technologies, experienced teachers sharing knowledge and differing pedagogical approaches to technology enhanced learning can influence the placement's learning value. As König, Jäger-Biela \& Glutsch (2020, p.617) found, "that means that those teachers who had already software resources at their disposal and were familiar with their use in teaching were clearly advantaged when school closures began". It is clear that the majority of student teachers surveyed believe that online teaching and learning is part of their teaching future. It was pointed out that the skills learned went 'far beyond online teaching' which reflects Ferdig et al's, (2009) view that "Blended teachers, in addition to being lecturers, counsellors and mentors to their students as most teachers are, are also expected to act as facilitators, instructional designers, site coordinators and network administrators for their schools, classrooms and fellow teachers". The responses of student teachers to the experience of online teaching reflect Northcote et al's observations of online educators as 1) the 'first generation' with little or no training, are wary of online learning; 2) the 'second generation' who have some experience of online teaching, have moved from why questions to technical questions; 3) the 'third question' with plenty of experience are looking for more information on "creative delivery and learning through experimentation" (2015 cited in Ni She et al., 2019, p.47). Overall, student teachers in this study show an acceptance of the future use of online teaching and learning in school environments and an understanding of the value of such learning for them as educators and for their students. There are also indications of an interest and a desire for more skills and knowledge in online teaching to augment what they already use and know in their individual practice and settings.

\section{Conclusion}

The purpose of this study was to evaluate the effectiveness of a COVID-19 response designed to prepare student teachers to teach online. The evaluation captured participants' responses under three broad themes. First, the effectiveness of the module in training student teachers for online placement in schools. Findings in this theme suggest that the intervention was successful in preparing participants to teach online. The range of content, delivery methods and assessment approaches allowed the participants to scaffold and structure their learning in a logical manner, while affording opportunities for practice and reflection. The peer evaluation elements were particularly successful in promoting critique and peer learning. Second, the benefits to student teachers from participating in the module. Findings in this theme suggest that student teachers' confidence and abilities with online teaching were greatly increased as a result of the intervention. The knowledge and skills attained during the module were not only relevant during the period of online teaching, but student teachers recognised their value in the future. Third, potential improvements to the intervention and in responding to student teachers needs in this area. Findings in this theme suggest that providing differentiated pathways for learning may be beneficial. The 'one size fits all' approach was appropriate as an emergency response. However, future interventions should consider strands which cater for those with little online teaching experience and more comprehensive strands for those who are comfortable in this area. This theme also highlighted the need to develop student teachers' understanding and use of peer-evaluations. These emerged as a positive tool for developing enabling critique and reflection. However, further exploration of the process and parameters may improve the quality of these evaluations.

\section{Recommendations}

Findings from this study suggest that participants valued the impact that the intervention had on their current and future practice. The students recognised the need to equip themselves with the competencies required to teach in a digitally connected world. Therefore, the authors recommend that ITE programmes consider incorporating modules that prepare students teachers to teach in online and blended learning environments. We believe that this has the dual benefit of future proofing student teachers' skill sets, while also having a positive impact on their ability to integrate technology in traditional face-to-face environments. The provision of teacher training in online teaching should incorporate distinct strands which accommodate student teachers with varying levels of experience. Providing alternative routes will ensure that student teachers that require basic training can be accommodated, while facilitating more experienced student teachers to quickly progress to more complex areas. While this study provided an account of 
student teachers perceptions of the intervention and its impact on their current and future practice, future studies could examine the experiences of post-primary students. Future work could focus also on examining online and blended solutions specifically tailored for post-primary subjects and investigate their effectiveness from the perspective of teachers and students.

\section{References}

Anderson, T. (2011). The theory and practice of online learning (2nd Edition). Edmonton, AB: AU Press.

Archibald, D. E., Graham, C. R., \& Larsen, R. (2021). Validating a blended teaching readiness instrument for primary/secondary preservice teachers. British Journal of Educational Technology, 52(2), 536-551. https://doi.org/10.1111/bjet.13060

Ashenafi, M. M. (2017). Peer-assessment in higher education-twenty-first century practices, challenges and the way forward. Assessment \& Evaluation in Higher Education, 42(2), 226-251. https://doi.org/10.1080/02602938.2015.1100711

Beltman, S., Glass, C., Dinham, J., Chalk, B., \& Nguyen, B. (2015). Drawing identity: Beginning pre-service teachers' professional identities. Issues in Educational Research, 25(3), 225.

Berger, J. B., \& Lyon, S. C. (2005). Past to present: A historical look at retention. In A. Seidman (Ed.), College student retention (pp. 1-29). Westport: Praeger Publishers.

Biggs, J. (1999). What the student does: Teaching for quality learning at university. Buckingham: Open University Press.

Beaunoyer, E., Dupéré, S., \& Guitton, M. J. (2020). COVID-19 and digital inequalities: Reciprocal impacts and mitigation strategies. Computers in human behavior, 111. https://doi.org/10.1016/j.chb.2020.106424

Caena, F., \& Redecker, C. (2019). Aligning teacher competence frameworks to 21st century challenges: The case for the European Digital Competence Framework for Educators (DigcompeDu). European Journal of Education, 54, 356-369. https://doi.org/10.1111/ejed.12345

Carrillo, C., \& Flores, M. A. (2020). COVID-19 and teacher education: a literature review of online teaching and learning practices. European Journal of Teacher Education, 43(4), 466-487. https://doi.org/10.1080/02619768.2020.1821184

Chau, P. (2010). Online higher education commodity. Journal of Computing in Higher Education, 22(3), 177-191. https://doi.org/10.1007/s12528-010-9039-y

Cohen, J. A. (2020). A fit for purpose pedagogy: Online learning designing and teaching. Development and Learning in Organizations, 35(4), 15-17. https://doi.org/10.1108/DLO-08-2020-0174

Creswell, J. W., \& Creswell, J. D. (2017). Research design: Qualitative, quantitative, and mixed methods approaches. Sage publications.

Daves, D., \& Roberts, J. (2010). Online teacher education programs: social connectedness and the learning experience. Journal of Instructional Pedagogies, 4, 455-461.

Dewey, J. (1938). Experience and Education. New York: Collier Books.

Downing, J. J., \& Dyment, J. E. (2013). Teacher educators' readiness, preparation, and perceptions of preparing preservice teachers in a fully online environment: An exploratory study. The teacher educator, 48(2), 96-109. https://doi.org/10.1080/08878730.2012.760023

Ferdig, R. E., Cavanaugh, C., DiPietro, M., Black, E. W., \& Dawson, K. (2009). Virtual Schooling Standards and Best Practices for Teacher Education. Journal of Technology and Teacher Education, 17(4), 479-503.

Filius, R. M., de Kleijn, R. A., Uijl, S. G., Prins, F. J., van Rijen, H. V., \& Grobbee, D. E. (2019). Audio peer feedback to promote deep learning in online education. Journal of Computer Assisted Learning, 35(5), 607-619. https://doi.org/10.1111/jcal.12363

Fuentes-Abeledo, E. J., González-Sanmamed, M., Muñoz-Carril, P. C., \& Veiga-Rio, E. J. (2020). Teacher training and learning to teach: an analysis of tasks in the practicum. European Journal of Teacher Education, 43(3), 333-351. https://doi.org/10.1080/02619768.2020.1748595 
Fuller, A. (2007). Critiquing theories of learning and communities of practice, in Hughes, J., Jewson, N. and Unwin, L. (Eds), Communities of Practice: Critical Perspectives, Routledge, Abingdon, OX. https://doi.org/10.4324/NOE0415364737.ch2

Garrison, D. R., Anderson, T., \& Archer, W. (1999). Critical inquiry in a text-based environment: Computer conferencing in higher education. The internet and higher education, 2(2-3), 87-105. https://doi.org/10.1016/S1096-7516(00)00016-6

Head, J. T., Lockee, B. B., \& Oliver, K. M. (2002). Method, media, and mode: Clarifying the discussion of distance education effectiveness. Quarterly Review of Distance Education, 3(3), 261-68.

Hodges, C., Moore, S., Lockee, B., Trust, T., \& Bond, A. (2020). The difference between emergency remote teaching and online learning. Educause review, 27, 1-12. Available at: https://er.educause.edu/articles/2020/3/the-difference-between-emergency-remote-teaching-and-online-learning \#fn11

Hurlbut, A. R. (2018). Online vs. traditional learning in teacher education: a comparison of student progress. American Journal of Distance Education, 32(4), 248-266. https://doi.org/10.1080/08923647.2018.1509265

Kidd, W., \& Murray, J. (2020). The Covid-19 pandemic and its effects on teacher education in England: how teacher educators moved practicum learning online. European Journal of Teacher Education, 43(4), 542-558. https://doi.org/10.1080/02619768.2020.1820480

König, J., Jäger-Biela, D. J., \& Glutsch, N. (2020) Adapting to online teaching during COVID-19 school closure: teacher education and teacher competence effects among early career teachers in Germany. European Journal of Teacher Education, 43(4), 608-622. https://doi.org/10.1080/02619768.2020.1809650

Lalor, J., Lorenzi, F., \& Justin, R. A. M. I. (2014). Developing professional competence through assessment: constructivist and reflective practice in teacher-training. Eurasian Journal of Educational Research, (58), 45-66. https://doi.org/10.14689/ejer.2015.58.6

Lee, K. (2017). Rethinking the accessibility of online higher education: A historical review. The Internet and Higher Education, 33, 15-23. https://doi.org/10.1016/j.iheduc.2017.01.001

López-Belmonte, J., Moreno-Guerrero, A. J., Pozo-Sánchez, S., \& López-Núñez, J. A. (2020). Efecto de la competencia digital docente en el uso del blended learning en formación profesional. Investigación bibliotecológica, 34(83), 187-205. https://doi.org/10.22201/iibi.24488321xe.2020.83.58147

Lorenzi, F., \& Rami, J. (2012). A dialogical approach to developing professional competence in assessment. In: Scanlon, Geraldine and Mulcahy, Carmel, (eds.) Towards Transformative Education. A multidisciplinary perspective on research and practice in Bulgaria and Ireland. Sofia University Press, Sofia.

Maloney, S., Hong-Meng Tai, J., Lo, K., Molloy, E., \& Ilic, D. (2013). Honesty in critically reflective essays: an analysis of student practice, Advances in Health Science Education, 18, 617-626. https://doi.org/10.1007/s10459-012-9399-3

Marton, F., \& Saljo, R. (1997). Approaches to learning. In F. Marton, D. Hounsell, \& N. Entwistle (Eds.), The experience of learning. Edinburgh: Scottish Academic Press.

Moore, J., Dickson-Deane, C., \& Galyen, K. (2011). E-learning, online learning and distance learning environments: Are they the same?. The Internet and Higher Education, 14(2), 129-135. https://doi.org/10.1016/j.iheduc.2010.10.001

Mottus, A., Kinshuk, Chen, N. S., Graf, S., Alturki, U., \& Aldraiweesh, A. (2018). Teacher facilitation support in ubiquitous learning environments. Technology, Pedagogy and Education, 27(5), 549-570. https://doi.org/10.1080/1475939X.2018.1544587

Ní Shé, C., Farrell, O., Brunton, J., Costello, E., Donlon, E., Trevaskis, S., \& Eccles, S. (2019). Teaching online is different: critical perspectives from the literature. Dublin: Dublin City University.

Noddings, N. (2004). Is teaching a practice? In Education and Practice. Upholding the Integrity of Teaching and Learning (pp. 159-170). Oxford: Blackwell Publishing.

Northcote, M., Gosselin, K. P., Reynaud, D., Kilgour, P., \& Anderson, M. (2015). Navigating the learning journeys of online teachers: Threshold concepts and self-efficacy. Issues in Educational Research, 25(3), 26. 
Pennel, W. R., Fishman, B. J., Yamaguchi, R., \& Gallagher, L. P. (2007). What makes professional development effective? Strategies that foster curriculum implementation. American Educational Research Journal, 44(4), 921-958. https://doi.org/10.3102/0002831207308221

Quality and Qualifications Ireland (QQI). (2020). The Impact of COVID-19 Modifications to Teaching, Learning and Assessment in Irish Further Education and Training and Higher Education. Available at: https://www.qqi.ie/Downloads/TheImpactofCOVID19ModificationstoTeaching,LearningandAssessmentinIrish FurtherEducation.pdf.

Ryan, S., Kaufman, J., Greenhouse, J., She, R., \& Shi, J. (2016). The effectiveness of blended online learning courses at the Community College level. Community College Journal of Research and Practice, 40(4), 285-298. https://doi.org/10.1080/10668926.2015.1044584

Saba, F., \& Shearer, R. L. (2018). Transactional distance and adaptive learning: Planning for the future of higher education. New York, NY: Routledge. https://doi.org/10.4324/9780203731819

Sadler D. R. (1998). Formative assessment: Revisiting the territory. Assessment in Education, 5(1), 77-84. https://doi.org/10.1080/0969595980050104

Shearer, R., Aldemirb L., Hitchcock T., Resig, J. J., Driver, J., \& Kohler, M. (2020). What students want: a vision of a future online learning experience grounded in distance education theory. American Journal of Distance Education, 34(1), 36-52. https://doi.org/10.1080/08923647.2019.1706019

Siemens, G. (2004). Elearnspace. Connectivism: A learning theory for the digital age. Elearnspace.org.

Singh, V., \& Thurman, A. (2019). How Many Ways Can We Define Online Learning? A Systematic Literature Review of Definitions of Online Learning (1988-2018), American Journal of Distance Education, 33(4), $289-306$. https://doi.org/10.1080/08923647.2019.1663082

Sutherland-Smith, W., \& Saltmarsh, S. (2010). Minding the P's for implementing online education: purpose, pedagogy, and practicalities, Australian Journal of Teacher Education, 35(7), 64-77. https://doi.org/10.14221/ajte.2010v35n7.6

Teaching Council of Ireland. (2015). School Placement [online]. Available at: https://www.teachingcouncil.ie/en/teacher-education/initial-teacher-education/school-placement.

Van Huizen, P., Van Oers, B., \& Wubbels, T. (2005). A Vygotskian perspective on teacher education. Curriculum Studies, 37(3), 267-290. https://doi.org/10.1080/0022027042000328468

Weschke, B., Barclay, R. D., \& Vandersall, K. (2011). Online teacher education: Exploring the impact of a reading and literacy program on student learning. Journal of Asynchronous Learning Networks, 15(2), $22-43$. https://doi.org/10.24059/olj.v15i2.174

Yildiz, E. P., \& İşman, A. (2016). Quality Content in Distance Education. Universal Journal of Educational Research, 4(12), 2857-2862. https://doi.org/10.13189/ujer.2016.041220

\section{Copyrights}

Copyright for this article is retained by the author(s), with first publication rights granted to the journal.

This is an open-access article distributed under the terms and conditions of the Creative Commons Attribution license (http://creativecommons.org/licenses/by/4.0/). 